\title{
Characterization of Legume Starches and Their Noodle Quality
}

\section{Wen-Chieh Sung}

Assistant Professor, Department of Hotel and Restaurant Management, Chia Nan University of Pharmacy and Science, Tainan, Taiwan 717, R.O.C., sungwill@mail.chna.edu.tw

Martha Stone

Professor, Department of Food Science and Human Nutrition, Colorado State University, Fort Collins, CO, U.S.A.

Follow this and additional works at: https://jmstt.ntou.edu.tw/journal

Part of the Life Sciences Commons

\section{Recommended Citation}

Sung, Wen-Chieh and Stone, Martha (2004) "Characterization of Legume Starches and Their Noodle Quality," Journal of Marine Science and Technology. Vol. 12: Iss. 1, Article 4.

DOI: $10.51400 / 2709-6998.2217$

Available at: https://jmstt.ntou.edu.tw/journal/vol12/iss1/4

This Research Article is brought to you for free and open access by Journal of Marine Science and Technology. It has been accepted for inclusion in Journal of Marine Science and Technology by an authorized editor of Journal of Marine Science and Technology. 


\title{
CHARACTERIZATION OF LEGUME STARCHES AND THEIR NOODLE QUALITY
}

\author{
Wen-Chieh Sung* and Martha Stone**
}

Key words: starch noodle, mung bean, chick pea, pinto bean.

\begin{abstract}
Physicochemical properties of starches isolated from Colorado grown legumes (chick peas, peanut beans, and pinto beans) were studied to find a feasible, less expensive source for making starch noodles. Surfactants, monoglycerides of fatty acids and sodium stearoyl lactylate at $0.5 \%$ of starch weight, were also combined with raw starch to prepare starch noodles. Cooking qualities of pinto bean and peanut bean starches were inferior to those of mung bean and/or chick pea starch noodles. Although mung bean starch is used commercially for making starch noodles, functional characteristics and sensory results on chick pea starch noodles show that chick peas are suitable sources for starch noodle manufacturing. Addition of surfactants did not improve cooking qualities of starch noodles. Mung bean starches showed the type $\mathrm{C}$ pattern starch and no pasting peak in its viscoamylogram. Starches of mung bean noodle do not leach into cooking water before they gelatinize to form a gel network-like structure.
\end{abstract}

\section{INTRODUCTION}

Oriental starch noodles are composed of starch and water. It is generally believed that the ideal raw material for starch noodles is mung bean starch [4]. Lii et al. [6] suggested that an ideal starch for starch noodle manufacturing should have high amylose content with a high iodine affinity value (6 to 7\%), restricted swelling, and a $C$-type Brabender viscosity pattern.

Lii and Chang [7] reported that starch noodles prepared from red bean starches were fairly high in quality, but red bean starches were not as good as mung bean starches for starch noodle manufacturing. Red bean starches had restricted swelling and a $C$-type Brabender viscoamylograms, but the iodine affinity $(4.83 \%)$ from red beans was not as high as that of mung

Paper Submitted 10/07/03, Accepted 12/15/03. Author for Correspondence: Wen-Chieh Sung. E-mail: sungwill@mail.chna.edu.tw.

*Assistant Professor, Department of Hotel and Restaurant Management, Chia Nan University of Pharmacy and Science, Tainan, Taiwan 717, R.O.C.

**Professor, Department of Food Science and Human Nutrition, Colorado State University, Fort Collins, CO, U.S.A. bean starch (6.0 to $7.5 \%)$ [7]. Starch noodles were prepared from pigeonpea and compared with mung bean starch noodles by Singh et al. [16], there was no difference in size or shape between pigeonpea and mung bean starch granules. They reported cooked pigeonpea starch noodles and mung bean starch noodles had similar sensory results [16]. Chang and Lii [3] compared the quality of starch noodles made from starches extracted from mung beans, sweet potatoes, cassava, and canna. All starch noodles made from tuber starches showed lower eating quality (sensory scores) than those of mung bean starch noodles [3].

Mestres et al. [11] indicated that amylose-based crystallites of mung bean starch, which were resistant to boiling water and strongly linked to one another by junction zones, could function as the network of wheat gluten in gluten-free mung bean vermicelli. The specific function of the amylose network could explain why gluten-free mung bean starch vermicelli, made with amylose content over $30 \%$, did not fall into short segments during cooking [11]. Xu and Seib [17] conjectured that cooked starch noodles were composed of micelles, paracrystalline fringe and filler mass phases. The micelle phase is highly organized retrograded segment of amylose molecules, which is resistant to acid and enzymes. The paracrystalline fringe is a less organized zone and can be attacked by acid and $\alpha$-amylase but not by isoamylase [17]. The filler mass or amorphous zone is most prominent zone in the cooked starch noodles, which are poorly organized and are accessible to all hydrolytic enzymes and acids. The filler mass helps bind adjacent two micelles by forming nonparallel double helical junction zones among the filler mass [17]. Mohri [12] reported that fatty acid esters were effective in decreasing viscosity and adhesive force of starch to promote the separation of frozen starch noodles.

This study attempted to link physicochemical properties of starch isolated from Colorado grown crops to find a feasible starch source for making starch noodles. Addition of selected surfactants, monoglycerides of concentrated glyceryl monostearate or sodium stearoyl lactylate, into starch noodle formulas also was evaluated. 


\section{MATERIALS AND METHODS}

\section{Isolation of Starch}

Chick peas (Cicer arietinum L.), pinto beans (Phaseolus vulgaris), peanut beans (Phaseolus vulgaris L.), and mung bean ( $P$. vulgaris) were grown at the Agricultural Experiment Station of the Department of Soil and Crop Sciences, Colorado State University, in 1997. Bean and pea starches were isolated by the Medcalf and Gilles method [10] with slight modifications. Starch yield (\%) was calculated as dry starch weight divided by original legume weight $\times 100$.

\section{Proximate Composition of Starches}

Moisture, ash, crude protein and crude fat were measured according to AACC [1] procedures 44-16, 0812, 46-13, and 30-10.

\section{Physicochemical Properties of Starches}

Amylograph viscosity of various starches was measured in duplicate using a Brabender Instrument (C.W. Brabender Instruments, Inc., South Hackensack, New Jersey) Visco/Amylo/Graph. A 9\% starch suspension of 40.5 grams starch and $450 \mathrm{~mL}$ distilled water was heated from $30^{\circ} \mathrm{C}$ to $90^{\circ}$ at a controlled rate of $1.5^{\circ} \mathrm{C}$ per minute, held at $90^{\circ} \mathrm{C}$ for 60 minutes, and then cooled at a rate of $1.5^{\circ} \mathrm{C}$ to $50^{\circ} \mathrm{C}$. Viscosity was recorded in Brabender Units (B.U.). Solubility and swelling power of various starches were evaluated at temperatures of $60,70,80$, and $90^{\circ} \mathrm{C}$ following the method of Leach et al. [5]. Water binding capacities of starches were evaluated by the procedure of Medcalf and Gilles [10].

\section{Particle Size of Various Legume Starches}

Dry starch samples were dehydrated at $110^{\circ} \mathrm{C}$ in an air-oven for 2 hours, then mounted on stubs and shadowed with $15 \mathrm{~nm}$ gold-palladium (60:40) at Hummer sputter coater (Technics EMS, Inc., Spring, VA). Samples of legume starches were observed by Philips Scanning Electron Microscopy 505 at an acceleration voltage of $20 \mathrm{Kev}$ and the images were captured by computer with a standard scale bar at three locations per sample.

\section{Iodine Affinity of Various Legume Starches}

The percentage of iodine affinity of various legume starches was determined according to the proce- dure of iodimetric determination of amylose [15].

\section{Starch Noodle Preparation}

Starch noodles were prepared by the method of Chen [4]. Surfactants, monoglycerides of concentrated glyceryl monostearate (MG) (Eastman Chemical Company, Kingsport, TN) and sodium stearoyl lactylate (SSL)(ICI Canada Inc., Branford, Ontario) at $0.5 \%$ of starch weight were also added to mung bean starches to make starch noodles. Strength of dry starch noodles was tested with the TA.XT2 Texture Analyzer (Texture Technologies Corp., Scarsdale, NY) with a Warner Bratzler steel blade.

Cooked weight was determined by weighing the rinsed cooked starch noodles and dividing by the dry sample weight after 30 minutes cooking. Cooking losses were determined by the methods of Lii and Chang (7).

Firmness of cooked starch noodles was measured as force by compression with the TA.XT2 Texture Analyzer. A special pasta blade and plate (probe TA47) was used to imitate the action of a tooth. Two strands of cooked samples were tested after 30 minutes cooking. Calibration distance for the blade was $6.0 \mathrm{~mm}$ and test distance was $5.7 \mathrm{~mm}$ with a test speed of 1.0 $\mathrm{mm} / \mathrm{sec}$. The slope of force versus time ( $\mathrm{g} / \mathrm{sec}$.) was converted to units of firmness $(\mathrm{g} / \mathrm{mm})$. Three firmness measurements were made per sample.

\section{Scanning Electron Microscopy Studies of Starch Noodles}

All uncooked starch noodles were prepared with a pasta maker (Popeil Pasta Products, Inc., Beverly Hills, CA). Dough was extruded directly into boiling water and heated for 5 seconds. Starch noodles were immediately transferred to cold water and kept for 3 minutes before being placed in the freezer $\left(-10^{\circ} \mathrm{C}\right)$ for 24 hours. Starch noodles were dried in a Food Dehydrator Model \# 7020 at a temperature range of 30 to $50^{\circ} \mathrm{C}$ for 8 hours after removed from the freezer. Starch noodles were then frozen with liquid nitrogen, and water was removed from specimens by vacuum drying with a Speed Vac SC 100 (Savant Instruments, Inc., Farmingdale, NY) attached to a Precision Vacuum Pump Model DDC 195 (Precision Scientific Inc., Chicago, IL) to dehydrate at a low drying rate for 6 hours at 0.1 microbar. Specimens were prepared and observed at the same condition as mentioned in starch samples.

\section{Sensory Evaluation of Starch Noodles}

Commercial mung bean starch noodles and three types of legume starch noodles (100\% mung bean starch, 
$50 \%$ mung bean starch and 50\% chick pea starch, $100 \%$ chick pea starch) were evaluated by 30 consumers. Starch noodle preparation followed the method of Chen [4] for making mung bean starch noodles with some modifications. Starch noodle samples and commercial mung bean starch noodles used as reference samples were cooked for 30 minutes. Thirty male and female students between the ages of 18 and 30 who were enrolled in a sensory evaluation course evaluated the samples.

Panelists were instructed to evaluate how much they liked appearance, texture, and overall acceptability of starch noodles on a hedonic scale. The same group of panelists also ranked four starch noodle samples for "degree of liking" of appearance, texture, and overall acceptability.

\section{Statistical Analysis}

A randomized complete block design was used with four types of legume starches representing treatment levels in three replications per treatment. Data were analyzed by analysis of variance programs using Statistical Analysis System [14]. Pearson correlation coefficients were used to determine the relationship between factors (solubility, swelling power, water binding capacity, iodine affinity, firmness, cooked weight, and solid loss of cooked samples). Hedonic scores obtained from sensory evaluation were statistically evaluated by analysis of variance with the Statistical Analysis System [14]. Rank totals required for significance at the $5 \%$ level $(\mathrm{p}<0.05)$ were obtained from Appendix: Table I-1 in "Principles of Sensory Evaluation of Food" [2]. Least squares means were used to identify differences between treatments at a 5\% significance level.

\section{RESULTS AND DISCUSSION}

\section{Chemical Composition}

Starch yields and proximate composition of various legume starches are listed in Table 1. Insoluble particles and bran of peanut bean and pinto bean were difficult to remove from the slurry, and some stayed mixed with starch after centrifugation. Naivikul and D'Appolonia [13] reported the amounts of starch recovered from pinto bean and mung bean flours were $38.3 \%$ and $34.5 \%$, respectively. Sodium hydroxide solution $(0.016 \mathrm{~N})$ and $70 \%$ ethanol was employed to enhance the isolation of starch [13]. They obtained starch from flour, which had lower protein content $($ mean $=0.34 \%)$ than our results $($ mean $=1.00 \%)$. Yield of chick pea starch from chick pea flour was $40 \%$ as reported by
Lineback and Ke [9]. They re-screened and washed the residual pulp to increase starch yield in the soaked chick pea flour, but the protein content of chick pea starch $(0.94 \%)$ was higher than the starch used in this research $(0.80 \%$ protein $)$. Yields of legume starches isolated from the wet mill method were lower than that of the method isolated from legume flours. Crude protein, crude fat, and ash content were not significantly different between various legume starches.

Physicochemical Characteristics of Legume Starches Pasting Behaviors

Viscoamylograms of various legume starches (9\%) are shown in Figure 1. The Brabender curve of mung bean starches revealed no pasting peak. The viscosity of mung bean starch continued to increase to a fairly high viscosity during heating and held for 60 minutes at $90^{\circ} \mathrm{C}$. Mung bean starch granules did not swell as much as the other starches. A high-swelling starch upon heating, such as waxy starches, will swell dramatically and then the internal bonding forces become weak and fragile with heating to $90^{\circ} \mathrm{C}$ and holding for 60 minutes. This phenomenon could be seen with a high pasting peak followed by extensive rapid thinning during cooking [8]. Mung bean starch is a restrictedswelling starch [8], and its viscoamylogram exhibits a restricted-swelling type Brabender viscosity curve. The restricted-swelling property may be due to the cross linkages within the starch granules. Therefore, there is no pasting peak for mung bean starches and the Brabender curve remains consistently high and increases with further cooking. All other starches were highly restricted-swelling starches. Their starch granules did not swell sufficiently to give a viscous paste during cooking with water. This may be due to very high

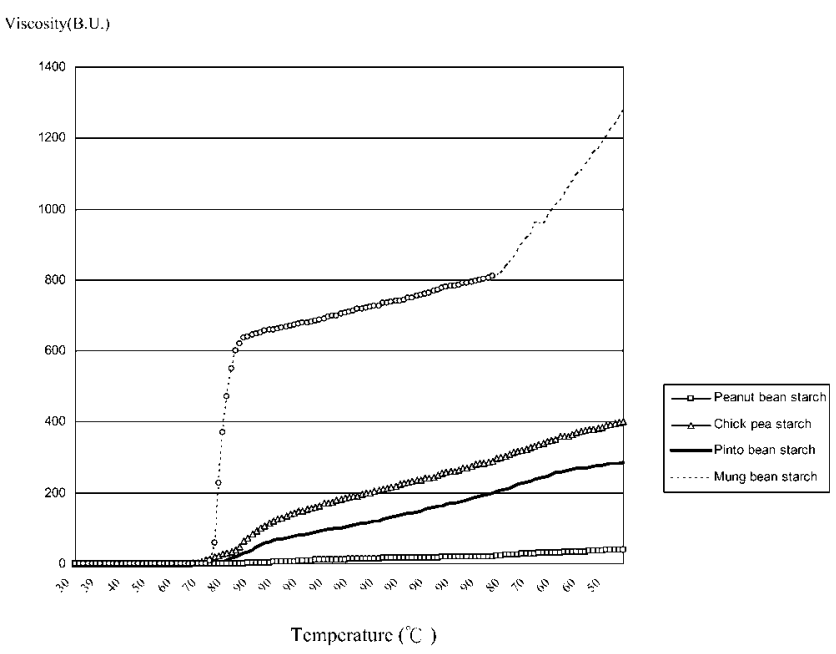

Fig. 1. Brabender viscoamylographs of various legume starches 
Table 1. Starch yield ${ }^{a}$ and proximate analysis of various legume starches ${ }^{b}$

\begin{tabular}{lccccc}
\hline \multirow{2}{*}{ Starch sample } & Yield & Moisture & Crude protein & Crude fat & Ash \\
\cline { 2 - 6 } & & & $\%$ & & \\
\hline Mung bean & & $9.7 \mathrm{a}$ & $0.8 \mathrm{a}$ & $0.1 \mathrm{a}$ & $0.1 \mathrm{a}$ \\
Chick pea & 25.3 & $6.0 \mathrm{~b}$ & $0.8 \mathrm{a}$ & $0.3 \mathrm{a}$ & $0.2 \mathrm{a}$ \\
Peanut bean & 13.8 & $5.1 \mathrm{c}$ & $1.1 \mathrm{a}$ & $0.3 \mathrm{a}$ & $0.2 \mathrm{a}$ \\
Pinto bean & 9.6 & $5.6 \mathrm{c}$ & $1.0 \mathrm{a}$ & $0.3 \mathrm{a}$ & $0.1 \mathrm{a}$ \\
\hline
\end{tabular}

${ }^{\text {a }}$ All values are a mean of 3 replications.

${ }^{\mathrm{b}}$ All values are a mean of 3 replications and 3 samples per replication.

Mean values with the same letter in the same column are not significantly different.

Table 2. Water binding capacities ${ }^{\text {a }}$ of various legume starches

\begin{tabular}{lc}
\hline \multirow{2}{*}{ Starch } & Water binding capacity \\
\cline { 2 - 2 } & $\%$ \\
\hline Mung bean & $233.7 \mathrm{a}$ \\
Chick pea & $487.4 \mathrm{~b}$ \\
Peanut bean & $629.6 \mathrm{~b}$ \\
Pinto bean & $560.3 \mathrm{~b}$ \\
\hline
\end{tabular}

${ }^{\text {a }}$ All values are a mean of 3 replications with 3 sub-samples per replication.

Mean values with the same letter in the same column are not significantly different.

amounts of amylose content or extensive cross-linkage between polymers. The $9 \%$ suspension of peanut bean starch showed no swelling and little change in viscosity during heating to $90^{\circ} \mathrm{C}$, holding for 60 minutes, or cooling from $90^{\circ} \mathrm{C}$ at a rate of $1.5^{\circ} \mathrm{C}$ per minute to $50^{\circ} \mathrm{C}$ (Figure 1).

The Brabender viscoamylogram of pinto bean starch showed a restricted type of swelling and contained no pasting peak on Brabender pasting profile [13] but mung bean starch gave much higher viscosity on a Brabender pasting curve than pinto bean starch. Lineback and Ke [9] reported Brabender viscoamylogram of chick pea starch was characterized by its resistance to swelling and fragmentation during heating. The Brabender viscoamylogram of chick pea starch curves were similar to those of starch produced from chemically cross-linked starches [9].

Water Binding Capacity, Swelling Power, Solubility and Iodine Affinity of Legume Starches

Results of water binding capacity for legume starches at $20^{\circ} \mathrm{C}$ are listed in Table 2. Mung bean starch had significantly lower water binding capacity than all other starch samples $(p<0.05)$. Solubility data for various legume starches at different temperatures are
Table 3. Solubility ${ }^{\mathrm{a}}$ of various legume starches at different temperatures

\begin{tabular}{lcccc}
\hline \multirow{2}{*}{ Starch } & \multicolumn{4}{c}{$\%$ Solubility at } \\
\cline { 2 - 4 } & 60 & 70 & 80 & 90 \\
\cline { 2 - 4 } & \multicolumn{4}{c}{${ }^{\circ} \mathrm{C}$} \\
Mung bean & $0.3 \mathrm{a}$ & $0.7 \mathrm{a}$ & $5.0 \mathrm{~b}$ & $1.1 \mathrm{a}$ \\
Chick pea & $2.7 \mathrm{a}$ & $4.8 \mathrm{c}$ & $2.5 \mathrm{a}$ & $1.2 \mathrm{a}$ \\
Peanut bean & $3.0 \mathrm{a}$ & $2.8 \mathrm{~b}$ & $5.0 \mathrm{~b}$ & $7.2 \mathrm{c}$ \\
Pinto bean & $0.9 \mathrm{a}$ & $1.1 \mathrm{a}$ & $2.9 \mathrm{a}$ & $5.9 \mathrm{~b}$ \\
\hline
\end{tabular}

${ }^{a}$ All values are a mean of 3 replications with 3 sub-samples per replication.

Mean values with the same letter in the same column are not significantly different.

presented in Table 3. Starch solubility of mung bean and chick pea increased with increasing temperatures then decreased after further increasing temperature to $90^{\circ} \mathrm{C}$. A possible reason for the decrease in solubility with increasing temperature in mung bean and chick pea starch samples is that gelatinized starch can prevent leaching of soluble material into water. Peanut bean and pinto bean starch solubility continued to increase with increased temperature. This could indicate that both peanut bean and pinto bean starches are not gelatinized completely under these test conditions. Therefore, both starch samples continued to dissolve into water. Peanut bean and pinto bean starch granules did not swell sufficiently to give a viscous paste during cooking in water. These results are confirmed with the curves from the Brabender Viscoamylograph (Figure 1).

Values for swelling power at different temperatures are listed in Table 4. In general, swelling power increased with increasing temperatures for all legume starches. Swelling powers of mung bean starch and chick pea starch were not significantly different at $90^{\circ} \mathrm{C}$, and they were higher $(p<0.05)$ than those of 
Table 4. Swelling powers ${ }^{\mathrm{a}}$ of various legume starches at different temperatures

\begin{tabular}{lcccc}
\hline \multirow{2}{*}{ Starch } & \multicolumn{4}{c}{ Swelling power at } \\
\cline { 2 - 4 } & 60 & 70 & 80 & 90 \\
\cline { 2 - 4 } & \multicolumn{5}{c}{${ }^{\circ} \mathrm{C}$} \\
Mung bean & $2.2 \mathrm{a}$ & $2.8 \mathrm{a}$ & $6.8 \mathrm{~b}$ & $10.4 \mathrm{~b}$ \\
Chick pea & $2.9 \mathrm{~b}$ & $5.9 \mathrm{c}$ & $8.7 \mathrm{c}$ & $9.8 \mathrm{~b}$ \\
Peanut bean & $3.5 \mathrm{c}$ & $5.2 \mathrm{~b}$ & $5.6 \mathrm{ab}$ & $6.3 \mathrm{a}$ \\
Pinto bean & $2.3 \mathrm{a}$ & $2.7 \mathrm{a}$ & $4.5 \mathrm{a}$ & $6.9 \mathrm{a}$ \\
\hline
\end{tabular}

${ }^{a}$ All values are a mean of 3 replications with 3 sub-samples per replication.

Mean values with the same letter in the same column are not significantly different.

peanut bean and pinto bean starches. Pinto bean starch generally had lower swelling power from $60^{\circ} \mathrm{C}$ to $90^{\circ} \mathrm{C}$ than the other legume starches.

Figure 2 shows scanning electron microscopy of various legume starches. Table 5 lists the iodine affinity and particle sizes of various legume starches. Chang and Lii (3) reported the size of mung bean starch granules ranged from $28.3 \times 15.6 \mu \mathrm{m}$ to $26.5 \times 16.8 \mu \mathrm{m}$ and its gelatinization temperature range was $62-67-73^{\circ} \mathrm{C}$. They reported iodine affinity and amylose content of mung bean starches showed the type $\mathrm{C}$ pattern and no pasting peak [3]. Its viscosity in Brabender Viscoamylogram was stable during heating and showed a high setback on cooling [3]. The diameter width ranged from 16 to $28 \mu \mathrm{m}$, while diameter length ranged from 16 to $48 \mu \mathrm{m}$ and 12 to $32 \mu \mathrm{m}$ for the pinto bean and mung bean starches, respectively [3]. Lineback and Ke [9] reported chick pea starch granule size ranges from large oval-shape (17 to $29 \mu \mathrm{m}$ ) to small spherical shape (6 to $7 \mu \mathrm{m})$.

Mung bean starch had significantly $(p<0.05)$

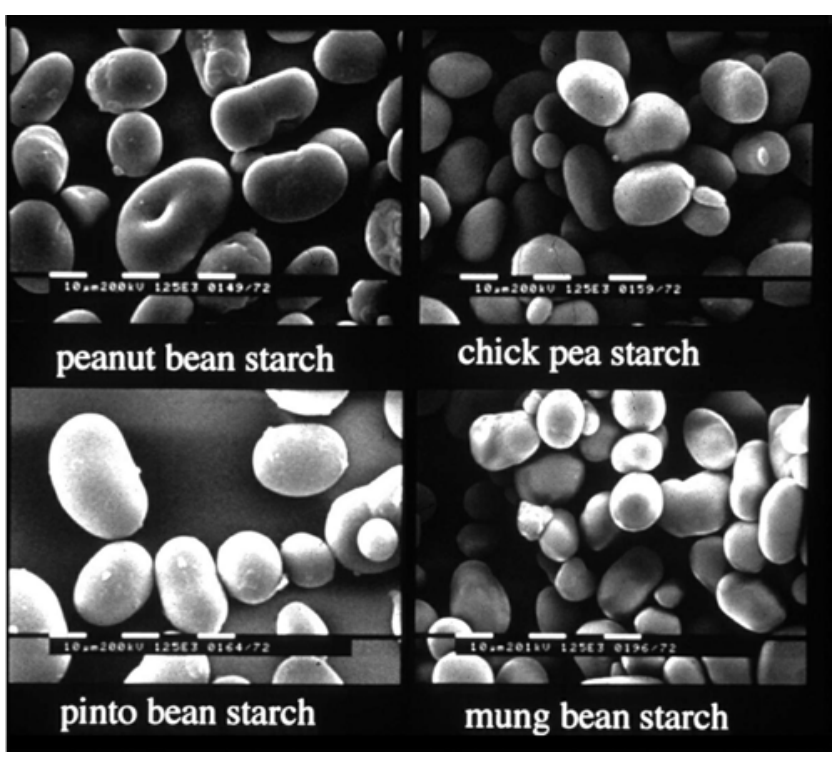

Fig. 2. Scanning electron microscopy of various legume starches $(\times 1,250)$.

lower iodine affinity than all the other starches. Lineback and $\mathrm{Ke}$ [9] reported the values of $6.08 \%$ for whole starch of chick pea. Their results agreed with the amylograms produced in the current study. Mung bean starch is a restricted-swelling starch, but all other starches are highly restricted-swelling starches. Starch granules of chick pea, peanut bean, and pinto bean starches did not swell sufficiently to give a viscous paste during cooking in water (Figure 1). This is due to higher amounts of amylose in those starches than mung bean starch. Naivikul and D'Appolonia [13] reported pinto bean starch contained higher amylose $(25.8 \%)$ than amylose of mung bean starch $(19.5 \%)$. The average granule size of peanut bean and pinto bean starches is larger $(p<$ 0.05 ) than mung bean and chick pea starches (Table 5). No large differences in size and shape of chick pea and

Table 5. Iodine affinity ${ }^{a}$ and particle size of various legume starches ${ }^{b}$

\begin{tabular}{|c|c|c|c|c|}
\hline Starch & $\%$ Iodine affinity & Granule shape & Length and width range $(\mu \mathrm{m})$ & Mean of length and width $(\mu \mathrm{m})$ \\
\hline \multirow[t]{2}{*}{ Mung bean } & \multirow[t]{2}{*}{$2.3 \mathrm{a}$} & Irregular (oval/ & $9.7-24.5$ & $17.7 \mathrm{a}$ \\
\hline & & round bean-shaped) & $8.1-22.7$ & $13.6 \mathrm{~d}$ \\
\hline \multirow[t]{2}{*}{ Chick pea } & \multirow[t]{2}{*}{$4.9 \mathrm{~b}$} & Irregular (oval/ & $8.1-28.5$ & $17.0 \mathrm{a}$ \\
\hline & & round bean-shaped) & 4.6-19.7 & $12.7 \mathrm{~d}$ \\
\hline \multirow[t]{2}{*}{ Peanut bean } & \multirow[t]{2}{*}{$6.3 b$} & Irregular (oval/ & $12.2-34.1$ & $22.0 \mathrm{~b}$ \\
\hline & & round bean-shaped) & $12.0-21.7$ & $16.0 \mathrm{e}$ \\
\hline \multirow[t]{2}{*}{ Pinto bean } & \multirow[t]{2}{*}{$5.6 \mathrm{~b}$} & Irregular (oval/ & $11.4-35.5$ & $24.8 \mathrm{c}$ \\
\hline & & round bean-shaped) & $11.0-28.4$ & $19.6 \mathrm{f}$ \\
\hline
\end{tabular}

\footnotetext{
a All values are a mean of 3 replications with 3 sub-samples per replication.

${ }^{\mathrm{b}}$ All values are a mean of 1 replication with 50 granule counts.

Mean values with the same letter in the same column are not significantly different.
} 
Table 6. Strength ${ }^{\mathrm{a}}$ of various dry starch noodles and functional characteristics of $\mathbf{3 0}$ minutes cooking ${ }^{\mathrm{b}}$ starch noodles

\begin{tabular}{lcccc}
\hline Starch noodle & Strength $(\mathrm{g})$ & \% Cooked weight & \% Cooking loss & Firmness $(\mathrm{g} / \mathrm{mm})$ \\
\hline Mung bean starch & $1909.4 \mathrm{a}$ & $645.7 \mathrm{ab}$ & $1.3 \mathrm{a}$ & $43.9 \mathrm{ab}$ \\
Chick pea starch & $1499.2 \mathrm{a}$ & $618.0 \mathrm{a}$ & $1.6 \mathrm{a}$ & $65.4 \mathrm{a}$ \\
Pinto bean starch & $784.2 \mathrm{~b}$ & $596.8 \mathrm{a}$ & $5.4 \mathrm{~b}$ & $62.1 \mathrm{a}$ \\
Mung bean starch + MG & $1983.4 \mathrm{a}$ & $695.0 \mathrm{~b}$ & $2.4 \mathrm{a}$ & $50.0 \mathrm{ab}$ \\
Mung bean starch + SSL & $1674.3 \mathrm{a}$ & $702.6 \mathrm{~b}$ & $3.1 \mathrm{a}$ & $37.4 \mathrm{~b}$ \\
\hline
\end{tabular}

${ }^{a}$ All values are a mean of 3 replications with 30 sub-samples per replication.

${ }^{\mathrm{b}}$ All values are a mean of 3 replications with 3 sub-samples per replication.

Mean values with the same letter in the same column are not significantly different.

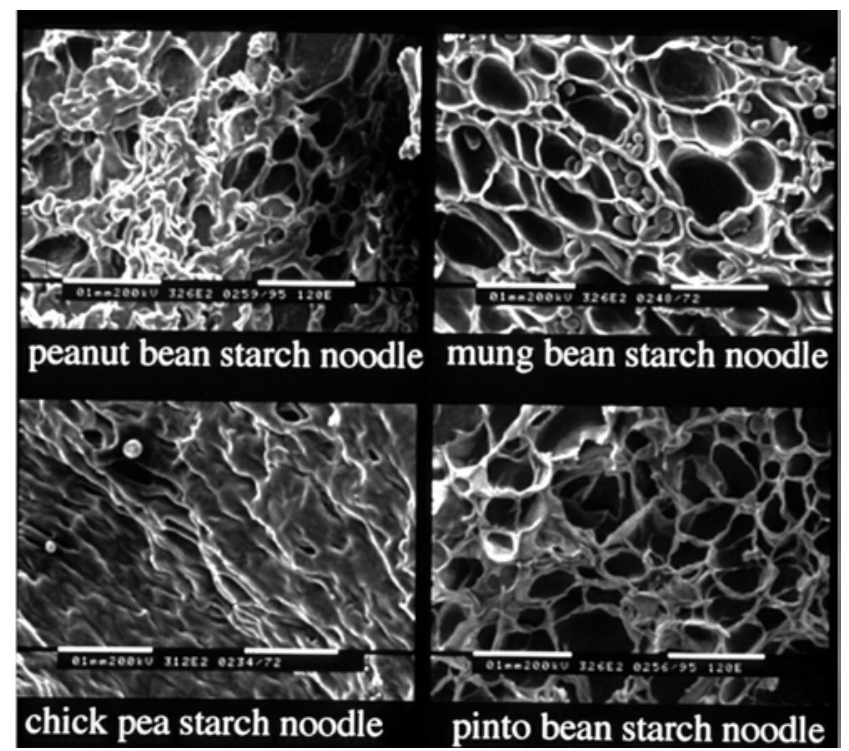

Fig. 3. Surfaces of starch noodles made from various legume starches $(\mathrm{SEM}, \times 326)$.

mung bean starch granules were observed (Table 5). Correlation analysis showed iodine affinity of legume starches was positively related to solubility of starch at $90^{\circ} \mathrm{C}(r=0.6)$. It indicates that starches having a higher iodine affinity will have higher solubility and lower swelling power at $90^{\circ} \mathrm{C}$. Because pinto bean starch is a highly restricted-swelling starch, and it contains higher amounts of amylose than mung bean starch, the amylose of starch granules leaches into cooking water before it gelatinizes. These factors may contribute to high solid losses in cooked pinto bean starch noodles. Water binding capacity was positively correlated with solubility of starch at $90^{\circ} \mathrm{C}(r=0.43)$, swelling power of starch at $60^{\circ} \mathrm{C}(r=0.41)$, iodine affinity of $\operatorname{starch}(r=0.58)$, and firmness $(p<0.05)$ of cooked starch noodles $(r=$ $0.55)$. Solubility of legume starches at 60 and $70^{\circ} \mathrm{C}$ was highly correlated $(p<0.05)$ to swelling power of legume starches at $60^{\circ} \mathrm{C}(r=0.51)$ and at $70^{\circ} \mathrm{C}(r=0.97)$, respectively. Nevertheless, solubility of legume starch at $90^{\circ} \mathrm{C}$ is negatively correlated $(p<0.05)$ with swelling power of legume starches at that same temperature $(r=$ -0.96). Starches generally had higher solubility at $90^{\circ} \mathrm{C}$, and starches also had low swelling power at that temperature.

\section{Scanning Electron Microscopy (SEM) of Starch Noodles}

Figure 3 shows surfaces of starch noodles made from various legume starches extruded directly into boiling water and heated for 5 seconds. There are still some starch granules within the gelatinized starch network of mung bean starch noodles. This indicates only mung bean starches do not leach into cooking water before they gelatinize. All other legume starches did not swell sufficiently under these conditions to give a viscous paste and leach into water. This may be caused by higher solubility of those starch noodles than mung bean starch noodles. Mestres et al. [11] reported that birefringent filamentous structures were detected within mung bean starch vermicelli, but no intact starch granules were observed. The X-ray diffraction pattern of mung bean starch vermicelli was typical of B-type. Chang and Lii [3] observed a gel network-like structure of mung bean starch noodle by scanning electron microscopy. Canna starch noodles showed some holes in cross sections of the gel network-like structure [3]. Cassava and sweet potato starch noodles only showed a pasty structure under SEM [3].

\section{Cooking Quality of Starch Noodles}

Dry starch noodle strength and functional characteristics of cooked starch noodles are presented in Table 6 . The strength of dry pinto bean starch noodles was weaker $(p<0.05)$ than the other starch noodles, indicating weak binding forces between pinto bean starches. Pinto bean starch noodles had the highest cooking losses when compared to other starch noodles (Table 6). This 
Table 7. Mean value ${ }^{\mathrm{a}}$ hedonic scores ${ }^{\mathrm{b}}$ for legume starch noodles

\begin{tabular}{lccc}
\hline \multirow{2}{*}{ Sample } & \multicolumn{3}{c}{ Characteristics } \\
\cline { 2 - 4 } & Appearance & Texture & Overall acceptability \\
\hline Commercial mung bean starch noodles & $4.6 \mathrm{a}$ & $4.5 \mathrm{a}$ & $4.5 \mathrm{a}$ \\
$100 \%$ mung bean starch noodles & $4.0 \mathrm{a}$ & $4.4 \mathrm{a}$ & $4.7 \mathrm{a}$ \\
$50 \%$ mung bean starch, 50\% chick pea starch noodles & $3.7 \mathrm{a}$ & $4.1 \mathrm{a}$ & $4.2 \mathrm{a}$ \\
$100 \%$ chick pea starch noodles & $3.3 \mathrm{a}$ & $4.0 \mathrm{a}$ & $3.9 \mathrm{a}$ \\
\hline
\end{tabular}

${ }^{a}$ Mean values (27 panelists) with the same grouping letter are not significantly different.

${ }^{\mathrm{b}}$ Scale: 1 = Like extremely; 2 = Like very much; 3 = Like slightly; 4 = Neither like nor dislike; 5 = Dislike slightly; 6 = Dislike very much; 7 = Dislike extremely.

Table 8. Total score ${ }^{\mathrm{a}}$ for ranking ${ }^{\mathrm{b}}$ test for legume starch noodles

\begin{tabular}{lccc}
\hline \multirow{2}{*}{ Sample } & \multicolumn{3}{c}{ Characteristics $^{\mathrm{c}}$} \\
\cline { 2 - 4 } & Appearance & Texture & Overall acceptability $^{\text {Commercial mung bean starch noodles }}$ \\
\hline 100\% mung bean starch noodles & 56 & 70 & 72 \\
$50 \%$ mung bean starch, 50\% chick pea starch noodles & 50 & 43 & 40 \\
$100 \%$ chick pea starch noodles & 41 & 42 & 48 \\
\hline
\end{tabular}

a Total scores < 41: like significant better; total scores > 64 liked significant less.

${ }^{\mathrm{b}}$ Based on: 1 = like best; 4 = like least.

${ }^{\mathrm{c}}$ Twenty-one panelists for evaluation.

could be related to their high iodine affinity and their highly restricted-swelling property. The addition of surfactants, monoglycerides of concentrated glyceryl monosterate (MG) and sodium stearoyl lactylate (SSL), increased cooking losses and cooked weights of starch noodles but produced noodles which were not different to the mung bean starch noodles used as a control. Addition of surfactants did not improve the cooking qualities of starch noodles under the conditions of this study. Firmness of cooked starch noodles was negatively correlated $(r=-0.64)$ to cooked weight of starch noodles $(p<0.05)$. Noodles with highest cooked weight were also softest. Texture of starch noodles made from highly restricted-swelling starches was slightly firmer than texture of mung bean starch noodles (Table 6).

Correlation analysis revealed that solid losses of cooked starch noodles were positively correlated ( $p<$ 0.05 and $r=0.90$ ) to solubility of legume starch at $90^{\circ} \mathrm{C}$, but negatively correlated $(r=-0.59)$ to solubility of legume starch at $70^{\circ} \mathrm{C}$. This suggests that legume starches have high solubility at $70^{\circ} \mathrm{C}$ and low solubility at $90^{\circ} \mathrm{C}$ and its starch noodles will have low solid losses during 30 minute cooking. Solid loss of starch noodles is negatively correlated to swelling power $(r=-0.56)$ of legume starches at all test temperatures $(p<0.05)$. Higher swelling power of starch ingredients produced lower solid losses in starch noodle products.

\section{Sensory Evaluation}

Table 7 shows mean hedonic scores from 27 panelists for appearance, texture, and overall acceptability of legume starch noodles. Although panelists showed a trend to prefer chick pea starch noodles in appearance, texture and overall acceptability, there was no statistical differences between those samples and the mung bean starch noodles. Table 8 shows total scores in a ranking test by 21 panelists. Results showed panelists liked the texture and overall acceptability of mung bean or chick pea starch noodles better than the commercial starch noodles $(p<0.05)$. Appearance of chick pea starch noodles was liked more than other noodles, but differences were not significant from other samples. Mung bean starch noodles had significantly better overall acceptability $(p<0.05)$.

\section{REFERENCES}

1. AACC, "Approved Methods of the AACC (10th ed.)," St. Paul, MN (1995).

2. Anson, M.L., Chichester, C.O., Mark, E.M., and Steward, G.F., Principles of Sensory Evaluation of Food. Aca- 
demic Press Inc., New York (1965).

3. Chang, S.M. and Lii, C.Y., "Characterization of Some Tuber Starches and Their Noodle Quality," Bull. Inst. Chem. Academia Sinica, Vol. 34, pp. 9-15 (1987).

4. Chen, C.Y., "The Noodle Qualities and Physicochemical Properties of Various Starches Isolated by Wet Process," M.S. Thesis, National Taiwan University, Taipei, Taiwan, R.O.C. (1978).

5. Leach, H.W., McCowen, L.D., and Schoch, T.J., "Structure of the Starch Granule I. Swelling and Solubility Patterns of Various Starches," Cereal Chem., Vol. 36, pp. 534-544 (1959).

6. Lii, C.Y., Chen, C.Y., and Wang, H.H., "Studies on the Processing and Qualities of Starch Noodles from Various Starches," ACS-CSJ Joint Meeting, Honoluulu, Hawaii (1979).

7. Lii, C.Y. and Chang, S.M., "Characterization of Red Bean (Phaseolus radiatus var. Aurea) Starch and Its Noodle Quality," J. Food Sci., Vol. 46, pp. 78-81 (1981).

8. Lii, C.Y., Chu, Y.L., and Chang, Y.H., "Isolation and Characterization of Mungbean Starch," Mungbean, Asian Vegetable Research and Development Center, Tainan, Taiwan, pp. 528-535 (1987).

9. Lineback, D.R. and Ke, C.H., "Starches and Low Molecular Weight Carbohydrates from Chick Pea and Horse Bean Flours," Cereal Chem., Vol. 52, pp. 334-347 (1975).
10. Medcalf, D.G. and Gilles, K., "Wheat Starches. I. Comparison of Physciochemical Properties," Cereal Chem., Vol. 42, pp. 558-567 (1965).

11. Mestres, C., Colonna, P., and Buleon, A., "Characteristics of Starch Networks within Rice Flour Noodles and Mung Bean Starch Vermicelli," J. Food Sci., Vol. 53, pp. 1809-1812 (1988).

12. Mohri, Z., "Interaction between Starch and Fatty Acid Esters in Frozen Starch Noodles," Agric. Biol. Chem., Vol. 44, pp. 1455-1459 (1980).

13. Naivikul, O. and D'Appolonia, B.L., "Characteristics of Legume Flours Compared with Wheat Flour. II. Starch," Cereal Chem., Vol. 56, pp. 24-28 (1979).

14. SAS Institute, Inc., "SAS User's Guide, Statistics, Version 6 Edition," SAS Institute, Cary, North Carolina (1995).

15. Schoch, T.J., "Iodimetric Determination of Amylose," Methods in Carbohydrate Chemistry. Vol. 4, Whistler, R.L. (Ed.), Academic Press, New York and London, pp. 157-160 (1964).

16. Singh, U., Voraputhaporn, W., Rao, P.V., and Jambunathan, R., "Physicochemical Characteristics of Pigeonpea and Mung Bean Starches and Their Noodle Quality, “ J. Food Sci., Vol. 54, pp. 1293-1297 (1989).

17. Xu, A. and Seib, P.A., "Structure of Tapioca Pearls Compared to Starch Noodles from Mung Beans," $J$. Food Sci., Vol. 70, pp. 463-470 (1993). 